\title{
The Use of Feature Film for Teaching Undergraduate Bioethics: Course Format and Assessment through Student Narratives
}

\author{
H. Russell Searight, PhD \\ Professor of Psychology \\ Lake Superior State University \\ Alyssa Burnash, Molly Campbell, Megan Chmielewski, Morgan Edmonds, Heather \\ Gregg, Lyndsey Ren Johnson, Ellie Lytle, Katelyn Mills, Natalie Nowak, Camdyn \\ Odykirk, Kaycie Rachels, Mikayla Schrotenboer, Sierra Strutz, Teresa VanDyke, \\ Sydney Zuke, and Michael Zurek \\ Lake Superior State University
}

Note. The multiple authorship of this paper reflects a partnership between students and faculty in assessing and describing the impact of the course, "Medical Ethics and Film." Students' insights, reflections, and examination of course content from their respective value systems and life context enriched the learning experience and provide valuable guidance for future versions of the course (Cook-Sather et al., 2014).

Abstract. Film is a form of engaging narrative being employed with greater frequency in undergraduate and graduate education. To optimize their pedagogical impact, it is important to carefully select films that address core course objectives. Additionally, viewing should be structured with written guidelines to direct the audience to consider the relevant dimensions associated with the instructional goals of the film. A course, "Medical Ethics and Film" is described to illustrate cinemeducation. In order to assess the impact of this recently developed course, students kept ongoing diaries in which they regularly wrote about their reactions to each film. Analysis of the diaries revealed that students routinely addressed the moral dilemmas portrayed and often applied specific ethical theories. While ethical theory is typically presented as a series of cognitive frameworks, students often expressed strong emotional reactions and frequently linked the dilemmas portrayed to their own life.

Pedagogical strategies to promote active learning are increasingly recommended for humanities courses (Blasco et al., 2018). While definitions vary, active learning is an approach in which traditional lectures are replaced with questions or problems that students reflect upon and for which they develop possible solutions or directions for further clarification (Andrews et al., 2016). Importantly, problemfocused and case-based activities, while deemphasizing memorization of content, may promote critical thinking skills (Smith, 2016). While there is growing emphasis on teaching college students how to think rather than what to think, the past 20 years have also witnessed a mandate for assessment and documentation of educational outcome. While content knowledge can be assessed with traditional course examinations and writing assignments, the development of critical thinking abilities including dialectical reasoning and relativistic thought are more challenging to evaluate. Particularly when learning outcomes include less objective goals such as increased self-awareness as well

InSight: A Journal of Scholarly Teaching 
as the ability to simultaneously analyze a dilemma from multiple value perspectives, qualitative assessment may be more appropriate.

The current paper has several purposes. First, the use of feature film as a vehicle for teaching topics in the humanities-specifically biomedical ethics-- is explored. Second, we provide a descriptive outline of a course format for a class with feature film as the foundation. Finally, the paper depicts the use of student diaries as a means of determining the impact of a new, non-traditional course.

\section{Feature Film for Teaching Bioethics}

Proponents of narrative in higher education assert that stories-depicted through multiple media--enhance retention of core concept and also facilitate their application to "real world "dilemmas (Mcquiggan et al., 2008; Mottet et al., 1999). Teaching ethics through narratives provides a level of realism which may enhance application of abstract philosophical concepts to human dilemmas. A carefully selected film can illustrate how bioethical dilemmas are complex, often ambiguous, and

Teaching ethics through narratives provides a level of realism which may enhance application of abstract philosophical concepts to human dilemmas. addressed with decisions that may be relativistic rather than "right or wrong" (Blasco et al., 2018). Ethics education is typically cognitively-focused with emotion and intuition seen as impediments to application of rational principles, rules, and guidelines (Blasco et al., 2018). However, when confronted with ethical dilemmas in one's personal or professional lives, strong emotion is often elicited. This affective experience, may, at least temporarily, obscure, logical analysis and application of cognitive principles (Blasco et al., 2018). Film by its very nature is likely to stimulate these affective reactions. However, particularly in areas such as ethics, while learners' emotional reactions may temporarily reduce objectivity, affective engagement may also enhance self-awareness and empathy for others (Law et al., 2015). While there are accounts of using film as one of multiple teaching strategies for courses in medical ethics, the current course featured film as the primary medium of instruction (Searight \& Allmayer, 2014). Most existing accounts of teaching bioethics through film describe the audience as students in professional programs such as medicine (Banos \& Bosch, 2015; Silverman, 1999), dentistry (Brett-MacLean et al., 2010), or nursing (Aleksandrova-Yankulovska, 2016). While there are a few accounts of using film clips to teach specific ethical concepts with undergraduates (Yap-Figueras, 2013) the postgraduate and professional school audience is given greater attention in the bioethics literature.

The subjective impact of a college class on students' knowledge, critical thinking, and ethical development is difficult to assess with traditional quantitative ratings or summative, end-of-semester written comments. To obtain a deeper picture of the impact of "Medical Ethics and Film" on students' cognitive-emotional experience as well as their critical thinking processes, students kept a diary throughout the semester. These personal journals were intended to be a venue for students to share their reactions and ethical commentary for each film. 


\section{Course Format}

"Medical Ethics and Film" is an elective course offered through the Honors programs at a small public undergraduate university in the Midwestern United States. The Honors program emphasizes interdisciplinary courses which, with permission of the Honors' director or the course instructor, are available to all students in the University.

The course format has been described in detail, elsewhere (Searight \& Allmayer, 2014). The initial two weekly meetings began with an overview of ethical theories often applied to biomedicine (see Appendix A). In subsequent meetings prior to viewing the film, these models were often elaborated upon with illustrative cases. In addition, the instructor may present historical information that helps students better understand the film. For example, in viewing the film, Miss Evers' Boys, some of the students were not familiar with the Tuskegee Syphilis Study or its broader implications for African-American healthcare. While many students had heard of Dr. Jack Kevorkian, (You Don't Know Jack), early "right to die" legal cases such as that of Karen Quinlan and Cruzan vs. Missouri (1990) and were not familiar to many students. Some students were also not aware of some of the details of the more recent Terri Schiavo case (Pence, 2016). A list of the films and the ethical issues which they address is presented in Appendix B.

In lieu of a lecture-discussion, two of the films were preceded by an interactive class exercise. The class re-enacted a classic case in medical ethics from 1962 when the first outpatient kidney dialysis clinic in the country opened in Seattle, Washington. With available technology and resources for only three patients at a time and at least 50 applicants for treatment, a committee of diverse community members and medical professionals was formed to decide who should receive dialysis. Based on a feature story in Life magazine, the group came to be known as the "God Committee," which evaluated each applicant along various dimensions such as earnings and religious affiliation to determine who should receive dialysis (Jonsen, 2007). After a brief explanation of the dilemma, the class divided into two groups, and each group enacted the "God Committee's decision-making based on patient background information. Students randomly selected one of the roles from the committee (housewife, clergy, businessman, etc.) and received specific information about the characteristics of each person seeking dialysis. These individuals were then rank ordered them according to their relative "worth" (Jonsen, 2007). Prior to watching the film Contagion, depicting an epidemic of infectious disease, students were provided with sample cases in which quarantine might be appropriate and were asked to determine who should be quarantined and the accompanying impact on these individuals (National Collaborating Centre for Healthy Public Policy, 2010).

Prior to watching each film, students received a set of questions to consider (see Appendix B for examples). The purpose of the questions was to direct students to the specific ethical dilemmas arising in the film. Several sources (Banos \& Bosch, 2015; Bluestone, 2000) emphasize the educational value of providing some structure as a context for viewing the film. Banos and Bosch (2015) note that many films have complicated plots and subplots, which may distract students away from the key ethical issues to be considered. They note that the film Awakenings, used in our course, 
depicting Oliver Sacks' study of treating patients with encephalitis ("sleeping sickness") has multiple educationally engaging themes such as the climate of a long term, custodial institutional setting (Banos \& Bosch, 2015). However, the key ethical issue is whether the patients or their representatives gave true informed consent to the experimental L-Dopa treatment and whether there were adverse effects of "waking up" after many years. The issue was compounded by the necessity of discontinuing the drug because of its pronounced side effects, leaving the patients to return to their former catatonic state. In contrast. Extreme Measures, also shown in the current course, is described by Banos and Bosch (2015) as having a "tight plot" focusing on the use of homeless people for medical research without their consent and raising the issue of whether the potential benefits of the investigations outweigh the possible harm to these socially disadvantaged research participants. While Banos and Bosch (2015) indicate that instructors may need to develop strategies for provoking post-viewing debate, we have not found that to be a particular concern. The questions the students were given in advance are written in such a way to initiate critical discussion (see Appendix B).

\section{Film Selection}

Films are selected based on several dimensions. One guiding principle is to provide a set of films that address the array of major issues in contemporary medical ethics in the United States. Additionally, films are selected that illustrate different conceptual models of moral reasoning applied to medicine. Several sources recommend specific movies for medical ethics instruction. Rosenthal's (2018) recent guide provides descriptions of ten films that address issues in clinical ethics. In her work, Rosenthal (2018), in addition to describing the film, provides background about the making of the film and some of the technical aspects selected. Additionally, Rosenthal (2018) places the film and the moral dilemmas involved in the context of the social history of that era.

One of the films, Side Effects, was chosen based upon Elliott's (2010) description in an essay about ethical issues involving pharmaceutical representatives. The screenplay was written by a woman who had had past experience as a pharmaceutical representative herself.

The only documentary film shown was Extremis, depicting patients, their families, and critical care physicians in a hospital's intensive care unit. The film was summarized in a special article in the Journal of the American Medical Association (Buchbinder, 2017)

In our university, students evaluate their courses at the end of the semester. These evaluations include numerical ratings on various dimensions (e.g., "The instructor began class on time") as well as comments about the relative strengths and weaknesses of the course and the instructor. These end-of the semester assessments have included student feedback on technical aspects of specific films. These comments have influenced film selections for future versions of the course.

While content is certainly the priority in film selections, technical and artistic aspects can diminish a movie's educational value. These elements were occasionally mentioned in the student diaries. For example, several students reported that watching a foreign language film with English subtitles (The Diving Bell and the Butterfly) 
introduced an element of distraction as illustrated by these diary excerpts: "I am personally not a fan of foreign films and found it difficult to follow the movie reading captions" and "A movie in French...I must say I was a little miffed at the idea of having to read subtitles on a full length movie." However, despite some students' frustration with subtitles, The Diving Bell and the Butterfly did receive praise for its technical aspects: "I have to say I really loved the cinematography and the artistic elements in this film."

The film Side Effects, while praised by some students as "less depressing than the other movies," was harshly critiqued on technical grounds:

I thought the film was hilarious. The lack of good editing, the awkward shots, the poor writing--all of it mustered a hilariously bad movie. To be honest, I could see the direction that the director and writers were trying to take. It's just unfortunate that the execution was so poor.

\section{Student Diaries as a Tool for Reflective Learning and Formative Assessment}

As noted above, students in the course were asked to maintain a diary in which they recorded their reactions to each week's film. "Medical Ethics and Film" had only been offered once in the past-approximately four years ago, and only traditional standardized ratings were used to assess the course at that time.

The diary method is useful in helping educators to understand the learning process and can be a form of communication between teachers and learners. The current student journals fall under the heading of "solicited diaries" (Hyers, 2018) with the broad general direction to provide reflection and feedback about how the films impacted the students. In addition to providing feedback to the instructor for film selection, the diaries also provide another source of course assessment. The diary entries allow useful insight into how the class actually impacted students' knowledge, critical thinking, and personal development.

To optimize the value of diary narratives, Hyers (2018) notes that students should be able to write about their experiences in a thoughtful and reflective manner. Additionally, it is important that the diarists experience openness and trust in how their writing will be used. Participants were informed at the outset of the class that their reflections and observations through their diaries would be used in a qualitative research paper which they would co-author. However, it was made clear that the entries would not be associated with a specific student's identity.

\section{Method}

\section{Participants}

Sixteen students' diaries were shared with the instructor. Fifteen of the students were female. Their class status ranged from first semester first year students to seniors who would be graduating at the end of the current academic year.

\section{Approach to Data Analysis}

In keeping with Hyer's (2018) description of the use of diaries as a form of qualitative data, the analysis reflected a combination of both "top down" and" bottom 
up" analysis (Hyers, 2018). The inductive component "gives voice" to participants' experiences while the deductive component is guided more by a priori categories of meaning (Hyers, 2018; p. 124), which are tentatively established before reviewing the narrative data. For this course, a purely inductive approach in which text is analyzed without preconceived objectives for themes and organized according to categories did not seem entirely appropriate since the "raw text" would likely center around the descriptions of the films themselves.

In analyzing the dairy entries, thematic analysis occurred through stages as described by Braun and Clarke (2012). In the initial step, there was a general overview of the diaries to become broadly familiar with the data. In the second step, initial codes were generated which provided labels for pieces of the narrative data. These codes inherently involved both description and interpretation. After coding has been completed, themes or patterns emerge (Braun \& Clarke, 2012). These dimensions are usually limited to 4-8 core descriptive concepts illustrated with specific examples of the narrative data. The themes are reviewed and then named (Braun \& Clarke, 2012).

\section{Results}

The results are presented as a set of themes, which are named and briefly described. Each theme is illustrated with direct excerpts from the diaries. These excerpts are presented with minimal editing to capture the colloquial style of the diaries.

\section{Theme \# 1: Viscerally Intense Emotion and Catharsis}

Many of the diary entries began with a description of an emotional experience. Feelings were often expressed with striking intensity:

(Wit) This movie honestly infuriated me to no end. The level of inhumane treatment of this woman was sickening.

(Side Effects) Ultimately this film left me disgusted with how incredibly unscrupulous and deceitful pharmaceutical companies are..."

(Wit) Many different emotions arose. My predominant emotion being anger...

Some of these expressions included an intense visceral experience or a strong impulse: (Miss Evers' Boys) At some point, I felt slightly sick to my stomach because the thought of what was going on... [The Tuskegee Syphilis Study] ...felt so real...It makes you think about how a situation like this could be happening right now... without us knowing.

(Side Effects) This film makes you want to rip your hair out.

In examining the flow of the narratives, it seemed that these expressions at the outset of the week's diary entry were almost cathartic. Once the emotion was express, the 
analysis of the film could then occur:

(Contagion) This movie was truly scary. Usually scary movies make me scared of the dark, this movie made me want to reach in my backpack and grab my hand sanitizer and dump the remaining $5 \mathrm{~mL}$ onto my hands. This movie was so scary because it seems like it is truly possible.

\section{Theme \#2: Recognition of a Moral Dilemma}

The journal entries revealed that in most instances, students clearly recognized the key moral issues depicted in the films. However, comments often addressed whether morally correct or incorrect behavior occurred without a good deal of elaboration. While the responses were not based upon a specific ethical theory (see Appendix A), concepts such as informed consent were invoked:

(Henrietta Lacks) I think it was very wrong that the cells were taken without permission or compensation for the family. However, it did do a lot of good for a lot of people. This is why it is a debatable concept to many people. To me it is easy. There was no permission, therefore it is unethical and immoral.

In addition to concepts such as informed consent, there were often expressions of the moral rightness or wrongness of actions depicted in the film:

(Awakenings) I think it was the right decision to test L-dopa drugs in one patient and obtain consent from his mother. It isn't shown much in the film but hopefully the effects of dopamine were already known before it was administered, especially in such large doses. I think the mother should have been informed about any potential side effects before obtaining consent.

(Whose Life is it Anyway) I myself am a firm believer in the right to die. As long as proper measures are taken to prevent those who are unable to make rational decisions (such as those with clinical depression or bipolar disorder) people with terminal illnesses should be allowed to have a physician take them out of life.

(Awakenings) Dr. Sayer was acting out of beneficence for his patients ...[by]... truly wanting to discover a medication or therapy method that would help these abnormally unresponsive institutional[ized] patients.

(Contagion) The autonomy of millions of people was compromised when the government began enforcing strict containment policies within major cities of the nation, not allowing for potentially ill people to vacate the city at the risk of death. -

\section{Theme 3: Use of Formal Ethical Theory}

Application of specific ethical theories, such as those summarized in Appendix A, and their accompanying constructs were evident in some journal entries. In these narratives, a specifically labeled ethical theory (e.g., utilitarianism, deontology, etc.) as well as key constructs from the theory were described. These accounts went 
beyond "right-wrong" or a single moral principle, such as autonomy or informed consent, to explain the reasons for moral decisions as well as their implications:

(Extreme Measures) Dr. Myrick, the physician conducting the research, justifies his work by saying that by sacrificing a few people, countless others will be able to be cured and able to walk again. His very utilitarian argument has little regard for the lives of the people that he is experimenting on.

The next excerpt, while drawing explicitly upon principlism, also illustrates the sequence of emotional catharsis being followed by cognitive analysis as described above. Once the emotion was expressed, the analysis could then occur:

(Miss Evers' Boys) - I'm honestly disgusted with the research conducted during the Tuskegee Syphilis Study, especially when considering the incredibly discriminatory attitudes and undercurrents towards African-Americans... Patients held no autonomy over their healthcare choices and no informed consent was ever acquired by participants within the syphilis research study which isn't ethically permissible according to principlist ideology

The ability to consider the dilemmas that the films portrayed from more than one ethical theory as well as an appreciation that different stakeholders might invoke distinct ethical frameworks was articulated by a few students. This journal entry examines the issue of a patient's minimally informed consent to an experimental cancer treatment and demonstrates an appreciation that different stakeholders' interests may be supported by distinct ethical theories. In this example, utilitarianism competes with Kant's deontology and principlism:

(Wit) ...from [the] utilitarian perspective the doctors may be justified in their actions if they believe they are going to advance cancer treatment practices through the study so they will be able to benefit many future patients. From a Kantian perspective, their behavior is unacceptable the... [physicians] are using Vivian as a means to an end with little regard for her own life. None of the principles of autonomy, beneficence, nonmaleficence are respected either.

\section{Theme \#4: Connections to Students' Personal Lives}

This theme emerged in several different ways. Some students related the film to a personal experience with serious illness in a family member or acquaintance or their own experience as a patient. Others referenced their work experience in health care settings or reflected upon their university educational experience.

In several diary entries, the narrative portrayed in the film elicited memories of current or recent experiences with family members:

(Extremis) This documentary made me pretty emotional... my grandmother passed away in early August this year. She went to the ER with a bad cold and they gave her medicine that she was allergic to so she had to stay the night, one night turned into two months. She never got out of the ICU, we still don't know what her cause of death was exactly. The ICU in the movie was exactly what my grandma went through. My ma was her POA so that made it even tougher for my family. She had to make decisions on if we should trach her or not .... what would my grandmother want...? 
This students' experience with their mother appeared in entries for two of the films:

(Diving Bell and the Butterfly) Lots of these things make me think of my mother and the stroke that she went through. I wonder how much relates to how she felt like waking up confused...

(Whose Life is it Anyway) My mom is paralyzed on her left side so she has no ability to use her left arm and leg. She can walk around a little. Her condition is in a sense half as bad as his.

Some students shared frustrating experiences as patients or wrote of negative experiences with the health care system. These themes were present in multiple films and elicited strong reactions. In the excerpt below, a student relates their experience of being denied a specific treatment because of tis cost:

(Side Effects) It's sad that this really happens but I know it does because I have.... Experienced medical decisions being made for me based on the price for medication... I've personally experienced doctors blowing me off and not paying attention to my care (something that is disrespectful and dangerous enough on its own) and then I looked down and realized they have expensive shoes and/or jewelry on. The sad fact in our capitalist society. [is that] ... medicine is a corporation as well.

Another type of personal connection was with students' work experience. Some students had worked or were currently working in healthcare and related fields such as a medical laboratory technician or emergency medical technician. These students often compared the film's treatment of a health care issue to their own experience working in the field:

(Extreme Measures) Dr. Myrick claims he has these humans in these tests because he has no time to wait and you might as well make homeless people useful. That mentally infuriates me. As a paramedic, I would never walk into someone's home after they call 911, ask if they have insurance, and if they say no pull out a separate drug box full of experimental drugs and just say well you're not paying solidity of these work."

(Side Effects) Pharmacy representatives (from what I know of them), do not have enough medical knowledge to be speaking to...physician about anything health related except their own personal health issues. It blows my mind that representatives are allowed to step behind the scenes in the physician and nursing stations to discuss medication. One thing that stands out to me is patient confidentiality. A nurse's or doctor's work space is littered in patient information. When a rep steps in to discuss medication, all of that information is subject to this random person.

Even when their work experience was not specifically in health care, a film might trigger an association of having been in a role of providing help to others:

(Diving Bell and the Butterfly) The film and what the speech therapist did helped me to be even more proud of some of the special needs kids I've worked with. It also reminded me to stay compassionate and loving toward students as I continue to work towards being a special education teacher. 
Several of the students in this course were completing preprofessional education for medical school or related professions. This journal entry describes how the course made a student aware that their education in the natural sciences may not have included adequate attention to accompanying moral and ethical issues:

(Henrietta Lacks) It truly bothers me that I'm just now learning about the origins of HeLa cells. In my senior year of undergraduate with an Associates in science and a minor in biochemistry how am I just now learning about Henrietta Lacks?

\section{Discussion}

The themes that emerged in students' written narratives about the course included consistent attention to the moral issues depicted in the films. While some of the of the analyses were at the level of labeling actions as morally correct or incorrect, other entries revealed analyses from the perspective of one or more ethical theories. Additionally, the ability to view these dilemmas from the perspective of multiple stakeholders, each of which would be supported by a distinct ethical model while not evident in the majority of diary entries, did appear with some frequency. Two unanticipated themes emerging from the diaries were the strong emotional reactions to bioethical dilemmas and the extent to which the films tapped into students' personal life experiences.

As noted above, students regularly recognized the moral dilemmas depicted in the films. The language in which they described these dilemmas was often in dichotomous terms of ethical versus unethical or right vs. wrong. While the journal entries were not analyzed by year level, it is possible that students who were further along in their university career were more likely to examine the films from the perspective of specific theories. Additionally, these more advanced students may well have also generated the entries which included simultaneous application of multiple ethical theories.

Perry's (1999) model of intellectual and moral development during the course of university education suggests that students move through distinct cognitive stages during their college years. According to Perry, students' initial exposure to postsecondary education is interpreted through the lens of Dualism-all dilemmas have definite, correct solutions. Authorities such as instructors and textbooks, hold these answers and the student's task is to learn the "right answer." While the universality of dualism as charactering most emerging adults who are new to college has been subjected to some criticism, Perry (1999) would likely argue that students, in analyzing ethical dilemmas depicted in the films from the dichotomous perspectives of ethical versus unethical or right versus wrong, reflected a dualist perspective.

In Multiplicity, Perry's next stage, students develop an appreciation for the fact that there are many situations for which the answer is not yet known. Multiplicity is characterized by reliance on personal intuition. This intuitive dimension was certainly evident in students' diaries. In Relativism, Perrier's third stage, there is an appreciation for context. In analyzing the moral dilemmas depicted in film, this context includes the models of ethical reasoning depicted in Appendix A. In this stage, there is recognition that multiple "truths" exist. While certainly providing multiple cognitive 
frameworks and an appreciation for diverse perspectives, this "pure" relativism does not lead to a clear direction for action.

In Perry's (1999) final stage, Commitment, there is an appreciation that multiple perspectives can simultaneously be "correct" and that one is left with some degree of uncertainty regarding moral decisions. However, at the same time, there is recognition that personal and professional decisions do indeed need to be made and acted upon even in the face of ambiguity. According to Perry (1999), the committed individual uses a combination of personal experience including well-articulated values as well as external evidence and a recognition that context may place some limits or parameters around the appropriate course of action. In this stage, decisions lead to the best possible course of action given one's values and the interpersonal context.

Our previous quantitative, pre-post assessment of an earlier version of this course (Searight \& Allmayer, 2014) suggested that, during the semester, students did develop a greater appreciation of the complexity of ethical decisions. During the first offering of this course, a standardized measure of critical thinking, the California Critical Thinking Disposition Inventory (CCTDI) was administered midway through the course and then again at the end of the semester. It was found that students' ratings demonstrated a pre- post- test increase on the CCTDI subscale, Maturity of Judgment. This construct assesses the extent to which students appreciate that many practical problems are complex and multi-faceted. Maturity of Judgment also measures the degree to which respondents recognize that it is often necessary to make decisions even when information is ambiguous or incomplete.

As is often the case with relatively open-ended qualitative assessment, the students' diaries revealed aspects of the course that while not specifically intended, certainly appeared to be beneficial. It was not anticipated that students would have been working in health-related fields. However, this experience was the case for a small student group, and their diary entries indicated that they thought about how the dilemmas portrayed in film would emerge and perhaps be addressed in their healthcare work setting.

An additional surprise was the extent to which students related film content to their personal experiences as patients and family members of patients. Again, medical ethics is often taught as an abstract set of principles and some degree of impersonality is actually encouraged so that principles can be applied neutrally and logically. While currently the source of some debate, the instructor has employed "trigger warnings" (American Association of University Professors, 2014; Boysen, 2017; Wyatt, 2016) in advance of presenting course topics and or video clips that might be distressing to students with histories of psychosocial trauma. It had not occurred to the instructor that perhaps these trigger warnings should be included in this course. While this instructor's experience has been that advance trigger warnings do not appear to impact class attendance when sensitive topics are raised, the preemptive warning does provide students with a form of psychological preparation.

One model of ethical decision making not well represented in bioethics (and not included in Appendix A) is the social intuitive approach associated with Moral Foundations Theory (MFT; Haidt et al., 2009). MFT argues that rather than being the result of principled logical reasoning, moral judgments are visceral, automatic reactions which are later justified with cognitive explanations. Key dimensions 
underlying these immediate value judgments include care/harm, fairness/cheating, loyalty/betrayal, authority/subversion and sanctity/degradation. While there have been a few attempts to integrate the social intuitive approach with virtue ethics (Leffel et al., 2015), this model, influenced by evolutionary theory has seen few applications to biomedical dilemmas.

In their written responses to the films, many of the students' diary entries followed the emotional-intuitive sequence of ethical decision-making described by Haidt (2012). A strong emotional reaction regarding the "rightness "or "wrongness" of a particular action depicted in the film was followed by cognitive analysis. Some proponents of social-intuitive ethics argue that the initial emotional response dictates the search for reasons that are congruent with this original visceral moral judgment. While it is not clear if students' intuitive responses led them directly to an explanation compatible with their feelings. The prominence of emotional reactions suggests that MFT should be included MFT in future versions of "Medical Ethics and Film.".

Film as a medium for ethics education can promote self-awareness by "lighting up" disruptive or disturbing parts of the self that otherwise might be ignored or neglected. Because the characters portrayed in movies are 'not real,' learners can be more honest about their reactions..." (Blasco et al., 2018; p. 80). According to Leffel and colleagues (2015), this type of self-awareness is "best accomplished by tuning-up (activating) moral intuitions, amplifying (intensifying) moral emotions related to intuitions, and strengthening (expanding) intuition-expressive, emotionrelated moral virtues, more than by 'learning' explicit ethical rules or principles"' (Leffel et al., 2015, p. 1371).

\title{
Conclusion
}

In teaching a new or non-traditional course, students' narrative feedback can be invaluable. While the emphasis on assessment typically requires pre-ordained class objectives before the class is actually underway, it is possible that a course may have significant educational benefit that is not anticipated. In evaluating a capstone undergraduate research experience, one of the benefits noted by students in a focus group was an experience of oneself as part of the community of scientists as well as having the experience of being in a professional role (Searight et al., 2010), neither of which were even considered as educational objectives. In addition to student learning and the development of critical thinking skills, diaries, as opposed to the traditional standardized rating scales used to assess course outcomes, may reveal a course's unintended benefits for students' cognitive and psychosocial development.

\section{References}

\begin{abstract}
Aleksandrova-Yankulovska, S. (2016). An innovative approach to teaching bioethics in management of healthcare. Nursing Ethics, 23(2), 167-175.

American Association of University Professors. (2014). On trigger warnings. https://www.aaup.org/report/triggerwarnings
\end{abstract}


Andrews, T. M., Leonard, M. J., Colgrove, C. A., \& Kalinowski, S. T. (2011). Active learning not associated with student learning in a random sample of college biology courses. CBE-Life Sciences Education, 10(4), 394-405.

https://doi.org/10.1187/ cbe.11-07-0061

Blasco, P. G., Moreto, G., \& Pessini, L. (2018). Using movie clips to promote reflective practice: A creative approach for teaching ethics. Asian Bioethics Review, 10(1), 75-85.

Boysen, G. A. (2017). Evidence-based answers to questions about trigger warnings for clinically-based distress: A review for teachers. Scholarship of Teaching and Learning in Psychology, 3(2), 163-177

Braun, V., \& Clarke, V. (2012). Thematic analysis. In H. Cooper (Ed.), APA handbook of research methods in psychology (vol. 2, pp. 57-71). American Psychological Association.

Brett-MacLean, P. J., Cave, M. T., Yiu, V., Kelner, D., \& Ross, D. J. (2010). Film as a means to introduce narrative reflective practice in medicine and dentistry: A beginning story presented in three parts. Reflective Practice, 11(4), 499-516.

Buchbinder, M. (2017). Extremis: A documentary look at end-of-life decisions in the ICU. JAMA, 317(3), 240-241.

Cook-Sather, A., Bovill, C., \& Felten, P. (2014). Engaging students as partners in learning and teaching: A guide for faculty. John Wiley \& Sons.

Cruzan v. Director, Missouri Department of Health, 497 U.S. 261 (1990)

Elliott, C. (2010). White coat, black hat: Adventures on the dark side of medicine. Beacon Press
Haidt, J. (2012). The righteous mind: Why good people are divided by politics and religion. Vintage.

Haidt, J., Graham, J., \& Joseph, C. (2009). Above and below left-right: Ideological narratives and moral foundations. Psychological Inquiry, 20(23), 110-119.

Hyers, L. L. (2018). Diary methods. Oxford University Press

Jonsen, A. R. (2007). The God squad and the origins of transplantation ethics and policy. The Journal of Law, Medicine $\mathcal{E}$ Ethics, 35(2), 238-240

Law, M., Kwong, W., Friesen, F., Veinot, P., \& Ng, S. L. (2015). The current landscape of television and movies in medical education. Perspectives on Medical Education, 4(5), 218-224

Leffel, G. M., Mueller, R. A. O., Curlin, F. A., \& Yoon, J. D. (2015). Relevance of the rationalist-intuitionist debate for ethics and professionalism in medical education. Advances in Health Sciences Education, 20(5), 1371-1383.

Mcquiggan, S. W., Rowe, J. P., Lee, S., \& Lester, J. C. (2008, June). Story-based learning: The impact of narrative on learning experiences and outcomes. In B. P. Woolf, E. Aïmeur, R. Nkambou, \& S. Lajoie (Eds.), International Conference on Intelligent Tutoring Systems (pp. 530-539). Springer.

Mott, B. W., Callaway, C. B., Zettlemoyer, L. S., Lee, S. Y., \& Lester, J. C. (1999, November). Towards narrative-centered learning environments. Paper presented at the Proceedings of the 1999 AAAI fall symposium on narrative intelligence (pp. 7882). 
National Collaborating Centre for Healthy Public Policy (2010). Ethical questions during a pandemic: Case studies. Ncchpp.ca

Perry, W. G. (1999). Forms of ethical and intellectual development in the college years: A scheme. Jossey-Bass.

Rosenthal, M. S. (2018). Clinical ethics on film: A guide for medical educators. Springer.

Searight, H. R., \& Allmayer, S. (2014,). The use of feature film to teach medical ethics: Overview and assessment. International Journal of Modern Education Forum, 3, 1-6.
Silverman, H. J. (1999). Description of an ethics curriculum for a medicine residency program. Western Journal of Medicine, 170(4), 228-231.

Smith, A. (2016). Experiential learning. Edward Elgar Publishing Limited.

Wyatt, W. (2016). The ethics of trigger warnings. Teaching Ethics, 16(1), 17-35.

Yap-Figueras, J. G. (2013). Case study discussion for students' comprehension of the four bioethics principles. West Visayas State University Research Journal, 2(2), 43-53.

Searight, H. R., Ratwik, S., \& Smith, T. (2010). "Hey, I can do this!": The benefits of conducting undergraduate psychology research for young adult development. InSight: A Journal of Scholarly Teaching, 5, 106114.

\section{Appendices}

Appendix A

Summary of Selected Ethical Theories Influencing Biomedicine

\begin{tabular}{|l|l|l|}
\hline Theory & Associated Theorist(s) & Key Concepts \\
\hline Deontology & Kant & $\begin{array}{l}\text { "Categorical Imperative" -absolute } \\
\text { moral principles; Duties; specific moral } \\
\text { rules to be followed People should } \\
\text { never be a means to an end }\end{array}$ \\
\hline Utilitarianism & Mill, Bentham & $\begin{array}{l}\text { Morally correct actions are those that } \\
\text { lead to the greatest benefit for the } \\
\text { greatest number of people }\end{array}$ \\
\hline Principlism & Beauchamp \& Childress & $\begin{array}{l}\text { Morally correct decisions require } \\
\text { attention to principles of Autonomy; } \\
\text { Beneficence; Non-Maleficence; Justice }\end{array}$ \\
\hline Libertarianism & Nozick & $\begin{array}{l}\text { Emphasizes moral character; Desirable } \\
\text { characteristics of health care provider } \\
\text { include prudence, self-effacement, } \\
\text { respect for persons, etc. }\end{array}$ \\
\hline
\end{tabular}

Sources: Beauchamp, T. L., \& Childress, J. F. (2013). Principles of Biomedical Ethics. (7 $7^{\text {th }}$ ed.). Oxford University Press. Pence, G. (2016). Medical ethics: Accounts of groundbreaking cases ( $8^{\text {th }}$ ed.). McGraw-Hill. 
Appendix B

Films from the Course, Associated Ethical Concepts, and Examples of Reflection Questions

\begin{tabular}{|c|c|c|c|}
\hline Film & Topic & Ethical Concepts & Example Questions \\
\hline Wit & $\begin{array}{l}\text { Professor receives } \\
\text { experimental } \\
\text { treatment for cancer } \\
\text { at the end of life }\end{array}$ & $\begin{array}{l}\text { Informed consent; } \\
\text { autonomy, } \\
\text { physician virtues; } \\
\text { Deontology }\end{array}$ & $\begin{array}{l}\text { Immediately after } \\
\text { presenting the } \\
\text { diagnosis, Dr. } \\
\text { Kelekian enrolls Dr. } \\
\text { Bearing in a } \\
\text { treatment study } \\
\text { that he is } \\
\text { overseeing. The } \\
\text { information that } \\
\text { should be } \\
\text { presented for } \\
\text { adequate patient } \\
\text { informed consent } \\
\text { for medical } \\
\text { research (compared } \\
\text { with conventional } \\
\text { treatment) should } \\
\text { be more detailed } \\
\text { with a clear } \\
\text { description of } \\
\text { possible risks. Do } \\
\text { you think that Dr. } \\
\text { Bearing's consent is } \\
\text { genuinely informed } \\
\text { ? }\end{array}$ \\
\hline $\begin{array}{l}\text { Whose Life is it } \\
\text { Anyway? }\end{array}$ & $\begin{array}{l}\text { Successful artist, } \\
\text { paralyzed after } \\
\text { accident, seeks to } \\
\text { end his life while in a } \\
\text { hospital }\end{array}$ & $\begin{array}{l}\text { Patient autonomy; } \\
\text { Right to die; } \\
\text { Beneficence; } \\
\text { Libertarianism }\end{array}$ & $\begin{array}{l}\text { Two elements that } \\
\text { Ken seems to see as } \\
\text { essential to } \\
\text { personhood are his } \\
\text { ability to function } \\
\text { sexually and his } \\
\text { ability to follow his } \\
\text { vocation as a } \\
\text { sculptor. What is } \\
\text { your assessment of } \\
\text { this definition? }\end{array}$ \\
\hline $\begin{array}{l}\text { You Don't Know } \\
\text { Jack }\end{array}$ & $\begin{array}{l}\text { Jack Kevorkian, } \\
\text { physician-assisted } \\
\text { suicide }\end{array}$ & $\begin{array}{l}\text { Patient autonomy; } \\
\text { Right to die; } \\
\text { patient decision- } \\
\text { making capacity; } \\
\text { Beneficence, Non- } \\
\text { maleficence; } \\
\text { Libertarianism }\end{array}$ & $\begin{array}{l}\text { In the early cases of } \\
\text { patients that he } \\
\text { assisted, Kevorkian } \\
\text { discusses organ } \\
\text { transplantation. At } \\
\text { one point he says to } \\
\text { a patient, your } \\
\text { organs can go to a }\end{array}$ \\
\hline
\end{tabular}

InSight: A Journal of Scholarly Teaching 


\begin{tabular}{|c|c|c|c|}
\hline & & & $\begin{array}{l}\text { more " useful" } \\
\text { citizen. Consider } \\
\text { this argument from } \\
\text { the ethical theories } \\
\text { used in medicine - } \\
\text { which perspective } \\
\text { would support his } \\
\text { statement and } \\
\text { which perspective } \\
\text { might not? }\end{array}$ \\
\hline $\begin{array}{l}\text { Extreme } \\
\text { Measures }\end{array}$ & $\begin{array}{l}\text { Homeless men are } \\
\text { used in a physician's } \\
\text { project to develop a } \\
\text { cure for hemi-paresis }\end{array}$ & $\begin{array}{l}\text { Deontology; } \\
\text { Utilitarianism, } \\
\text { Informed Consent }\end{array}$ & $\begin{array}{l}\text { Dr. Myrick makes } \\
\text { the case that by } \\
\text { having homeless } \\
\text { men participate in } \\
\text { his research, he has } \\
\text { provided them with } \\
\text { a productive role } \\
\text { which contributes } \\
\text { to society. From the } \\
\text { perspective of } \\
\text { ethical theories, } \\
\text { could Myrick's } \\
\text { position be } \\
\text { supported? Which } \\
\text { ethical principles } \\
\text { would be invoked } \\
\text { to dispute this } \\
\text { practice? }\end{array}$ \\
\hline Contagion & $\begin{array}{l}\text { A disease epidemic } \\
\text { without a cure or } \\
\text { vaccine for } \\
\text { prevention causes } \\
\text { large-scale social } \\
\text { breakdown }\end{array}$ & $\begin{array}{l}\text { Ethical issues } \\
\text { arising in an } \\
\text { epidemic; Justice in } \\
\text { allowing access to } \\
\text { limited resources; } \\
\text { Utilitarianism }\end{array}$ & $\begin{array}{l}\text { Beginning with the } \\
\text { funeral director, } \\
\text { altruistic motives } \\
\text { appear to be } \\
\text { evaporating. Do } \\
\text { you think that, in a } \\
\text { situation of this } \\
\text { type, most people } \\
\text { would be "out for } \\
\text { themselves," (e.g., } \\
\text { stealing food, } \\
\text { refusing to help } \\
\text { others who are ill)? }\end{array}$ \\
\hline Side Effects & $\begin{array}{l}\text { Pharmaceutical } \\
\text { industry; new drug } \\
\text { with known serious } \\
\text { side effects marketed } \\
\text { by pharmaceutical } \\
\text { representative with }\end{array}$ & $\begin{array}{l}\text { Honesty, Integrity; } \\
\text { Virtues; Conflicts } \\
\text { of Interest }\end{array}$ & $\begin{array}{l}\text { Physicians often } \\
\text { insist that } \\
\text { pharmaceutical } \\
\text { representatives and } \\
\text { the gifts they } \\
\text { provide have no } \\
\text { impact on their }\end{array}$ \\
\hline
\end{tabular}




\begin{tabular}{|c|c|c|c|}
\hline & $\begin{array}{l}\text { minimal knowledge } \\
\text { of pharmacotherapy }\end{array}$ & & $\begin{array}{l}\text { prescribing } \\
\text { practices. Do you } \\
\text { think this is true? }\end{array}$ \\
\hline Miss Evers' Boys & $\begin{array}{l}\text { Tuskegee syphilis } \\
\text { study; Research } \\
\text { Ethics; Informed } \\
\text { Consent; } \\
\text { Exploitation of } \\
\text { minority populations }\end{array}$ & $\begin{array}{l}\text { Elements of } \\
\text { Informed Consent } \\
\text { in Research; } \\
\text { Deception; } \\
\text { Utilitarianism; } \\
\text { Deontology }\end{array}$ & $\begin{array}{l}\text { It appears that the } \\
\text { U.S. Public Health } \\
\text { Service had } \\
\text { stereotypes about } \\
\text { the African } \\
\text { American men } \\
\text { being "treated." } \\
\text { What were these } \\
\text { stereotypes? How } \\
\text { did these views } \\
\text { influence the choice } \\
\text { of participants for } \\
\text { the study? }\end{array}$ \\
\hline Extremis & $\begin{array}{l}\text { Documentary } \\
\text { depicting families } \\
\text { and patients in a } \\
\text { hospital intensive } \\
\text { care unit engaged in } \\
\text { end-of-life decision- } \\
\text { making }\end{array}$ & $\begin{array}{l}\text { Decision-making } \\
\text { processes about } \\
\text { continued } \\
\text { treatment and life } \\
\text { support in } \\
\text { seriously ill } \\
\text { patients; Decision- } \\
\text { making capacity; } \\
\text { Family dynamics } \\
\text { in end-of-life care }\end{array}$ & $\begin{array}{l}\text { In discussions } \\
\text { between family } \\
\text { members as well as } \\
\text { between families } \\
\text { and physicians, } \\
\text { which ethical } \\
\text { principles appear to } \\
\text { be particularly } \\
\text { influential? }\end{array}$ \\
\hline $\begin{array}{l}\text { The Diving Bell } \\
\text { and the Butterfly }\end{array}$ & $\begin{array}{l}\text { Elle Editor, Jean- } \\
\text { Dominique Beauby } \\
\text { suffers a massive } \\
\text { stroke and is left } \\
\text { with "locked in } \\
\text { syndrome" in which } \\
\text { he is nearly } \\
\text { completely } \\
\text { paralyzed but his } \\
\text { cognitive functioning } \\
\text { is preserved }\end{array}$ & $\begin{array}{l}\text { Personhood; } \\
\text { Autonomy; } \\
\text { Deontology }\end{array}$ & $\begin{array}{l}\text { John Hardwig, a } \\
\text { medical ethicist, } \\
\text { wrote an article } \\
\text { entitled, "What } \\
\text { about the family?" } \\
\text { in which he argues } \\
\text { that the family of } \\
\text { the patient has } \\
\text { rights and } \\
\text { responsibilities in } \\
\text { situations like that } \\
\text { depicted in the film. } \\
\text { It appears that } \\
\text { Beauby's social } \\
\text { network (health } \\
\text { care staff, family, } \\
\text { friends, ex-wife, } \\
\text { and mistress) want } \\
\text { Beauby to continue } \\
\text { living. Does he } \\
\text { have any duties or }\end{array}$ \\
\hline
\end{tabular}




\begin{tabular}{|c|c|c|c|}
\hline & & & $\begin{array}{l}\text { responsibilities to } \\
\text { these people? }\end{array}$ \\
\hline Awakenings & $\begin{array}{l}\text { Patients who, as a } \\
\text { result of the } \\
\text { encephalitis } \\
\text { epidemic of 1917-18, } \\
\text { are in a catatonic } \\
\text { state, are treated } \\
\text { with L-Dopa. They } \\
\text { "awaken" but after } \\
\text { several months, } \\
\text { develop pronounced } \\
\text { side effects and the } \\
\text { treatment is } \\
\text { withdrawn. }\end{array}$ & $\begin{array}{l}\text { Physician Virtues; } \\
\text { Utilitarianism; } \\
\text { Autonomy; } \\
\text { Beneficence; Non- } \\
\text { maleficence; } \\
\text { Informed Consent }\end{array}$ & $\begin{array}{l}\text { Was the impact of } \\
\text { patients being } \\
\text { "awakened' and } \\
\text { recognizing that } \\
\text { they had lost } \\
\text { decades of their } \\
\text { lives given } \\
\text { consideration in } \\
\text { using L-Dopa } \\
\text { treatment? }\end{array}$ \\
\hline
\end{tabular}

H. Russell Searight is Professor of Psychology at Lake Superior State University. He received his PhD in Clinical Psychology from Saint Louis University and later earned a Masters of Public Health from Saint Louis University School of Public Health. His current research interests include the use of qualitative methods for educational assessment, the impact of higher education on emerging adults' psychosocial development, the social history of psychology and psychiatry, and medical ethics

Alyssa Burnash is currently completing BS degrees in both Psychology and Criminal Justice at Lake Superior State University.

Molly Campbell received her BS in Biochemistry from Lake Superior State University in spring, 2019. She is currently in her first year of medical school (MD class of 2023) at the University of Ottawa Faculty of Medicine.

Megan Chmielewski received her BS in Biology from Lake Superior State University in Spring, 2019. She is currently a Laboratory Technician for Betco Corporation.

Morgan Edmonds is currently completing a BS in International Business with a minor in Accounting at Lake Superior State University.

Heather Gregg received her BS in Biology with a minor in Biochemistry from Lake Superior State University in Spring, 2019. She is currently in the graduate program in Molecular Biology at Michigan State University.

Lyndsey Ren Johnson is currently completing a BS in Psychology with a minor in Theatre at Lake Superior State University.

Ellie Lytle received a BS in Psychology with a minor in Biochemistry from Lake Superior State University in Spring, 2019. She is planning on entering a Physician Assistant graduate program. 
Katelyn Mills received her BS in Psychology with a minor in Counseling from Lake Superior State University in Spring, 2019. She is currently pursuing a Master's degree in Experimental Psychology at Oakland University in Auburn Hills, Michigan

Natalie Nowak is completing a BS in Psychology with an additional concentration in Special Education at Lake Superior State University.

Camdyn Odykirk is currently completing a BS in Premedical Studies with a major in Biology and a minor in Chemistry at Lake Superior State University.

Kaycie Rachels is currently completing a BS degree and is in the Pre-Nursing program at Lake Superior State University.

Mikayla Schrotenboer is currently completing a BS in Nursing at Lake Superior State University.

Sierra Strutz will be completing her BS degree in Biochemistry and Associate's Degree in Chemistry at Lake Superior State University in Spring, 2020.

Teresa VanDyke is currently completing a BS degree in Fire Science with a minor in Paramedic Technology at Lake Superior State University.

Sydney Zuke is currently completing a BS in Kinesiology with a concentration in Rehabilitation Sciences and a minor in Biology at Lake Superior State University.

Michael Zurek is currently completing a BS in Computer Science at Lake Superior State University

"First, engaging in SoTL improves student learning because it affects how faculty members think about teaching and learning opportunities for their students. Second, contributions to the field of teaching are improved and enhanced. Third, engaging in

SoTL enriches one's experiences as a teacher."

Cathy Bishop-Clark (2012). Engaging in the Scholarship of Teaching and Learning: A Guide to the Process and How to Develop a Project from Start to Finish 